\title{
Dopamine $\mathrm{D}_{1}$ Activation Potentiates Striatal NMDA Receptors by Tyrosine Phosphorylation-Dependent Subunit Trafficking
}

\author{
Penelope J. Hallett, Robert Spoelgen, Bradley T. Hyman, David G. Standaert, and Anthone W. Dunah \\ MassGeneral Institute for Neurodegenerative Disease, Harvard Medical School and Massachusetts General Hospital, Charlestown, Massachusetts 02129
}

\begin{abstract}
Interactions between dopaminergic and glutamatergic afferents in the striatum are essential for motor learning and the regulation of movement. An important mechanism for these interactions is the ability of dopamine, through $\mathrm{D}_{1}$ receptors, to potentiate NMDA glutamate receptor function. Here we show that, in striatal neurons, $\mathrm{D}_{1}$ receptor activation leads to rapid trafficking of NMDA receptor subunits, with increased NR1 and NR2B subunits in dendrites, enhanced coclustering of these subunits with the postsynaptic density scaffolding molecule postsynaptic density-95, and increased surface expression. The dopamine $\mathrm{D}_{1}$ receptor-mediated NMDA receptor trafficking is blocked by an inhibitor of tyrosine kinases. Blockers of tyrosine phosphatases also induce NMDA subunit trafficking, but this effect is nonselective and alters both NR2A- and NR2B-containing receptors. Furthermore, tyrosine phosphatase inhibition leads to the clustering of tyrosine-phosphorylated NR2B subunit along dendritic shafts. Our findings reveal that $\mathrm{D}_{1}$ receptor activation can potentiate striatal NMDA subunit function by directly promoting the surface insertion of the receptor complexes. This effect is regulated by the reciprocal actions of protein tyrosine phosphatases and tyrosine kinases. Modification of these pathways may be a useful therapeutic target for Parkinson's disease and other basal ganglia disorders in which abnormal function of striatal NMDA receptors contributes to the symptoms of the diseases.
\end{abstract}

Key words: glutamate receptors; NMDA receptors; dopamine receptors; striatal neurons; tyrosine phosphorylation; receptor trafficking

\section{Introduction}

The striatum, the major input structure for the basal ganglia, receives convergent input from two principal sources: dopaminergic afferents from the substantia nigra pars compacta and glutamatergic afferents from the cerebral cortex. Interactions between these two types of inputs are a critical mechanism for acquisition of motor learning and regulation of movement (Di Chiara et al., 1994; Chase, 2004). The targets of the excitatory input from the cortex are the striatal medium spiny projection neurons, which make up $\sim 90 \%$ of the cells (Kawaguchi et al., 1995). Excitatory corticostriatal afferents synapse on the heads of the dendritic spines of these neurons in which the effects of glutamate are mediated by both NMDA and non-NMDA glutamate receptors (Smith et al., 1994; Levine et al., 1996; Cepeda et al., 1998). The dopaminergic inputs terminate principally on the shafts of the

\footnotetext{
Received Dec. 9, 2005; revised March 24, 2006; accepted March 27, 2006.

This work was supported by National Institutes of Health (NIH) Grant K01NS049006 and a Harvard Medical School Center of Excellence in Minority Health and Health Disparities Faculty Fellowship (A.W.D.), NIH Grant NS34361 (D.G.S.), and a grant from The National Parkinson's Foundation (P.J.H.). We thank Drs. Barry Wolfe (Georgetown University, Washington, DC), Morgan Sheng (Massachusetts Institute of Technology, (ambridge, MA), and Hugh Hemmings (Cornell University, Ithaca, NY) for kind gifts of antibodies, and Christine Keller-McGandy, Tiffany Collins, and Miya Bernson for expert assistance.

Correspondence should be addressed to Dr. Anthone W. Dunah, MassGeneral Institute for Neurodegenerative Disease, Massachusetts General Hospital, 114 16th Street, B114-2125, Charlestown, MA 02129. E-mail: dunah@helix.mgh.harvard.edu.

DOI:10.1523/JNEUROSCI.0792-06.2006

Copyright $\odot 2006$ Society for Neuroscience $\quad$ 0270-6474/06/264690-11\$15.00/0
}

spines and exert a strong modulatory action on the cortical inputs (Hersch et al., 1995; Smith et al., 1998).

An important aspect of the striatal dopamine-glutamate interactions is the ability of dopamine receptor activation to modulate the strength of the corticostriatal synapse. In both striatal slice preparations and acutely dissociated striatal neurons, dopamine or selective $\mathrm{D}_{1}$ receptor agonists potentiate NMDA receptor currents (Cepeda et al., 1993, 1998; Levine et al., 1996; FloresHernandez et al., 2002). Dopamine $\mathrm{D}_{1}$ activation is also required for the induction of striatal long-term potentiation, an NMDAdependent form of synaptic plasticity induced by stimulation of the corticostriatal pathway (Kerr and Wickens, 2001; Centonze et al., 2003). Several pathways have been implicated in the dopamine $\mathrm{D}_{1}$ receptor regulation of striatal NMDA receptors, including intracellular $\mathrm{Ca}^{2+}$ (Liu et al., 2004) and the action of protein kinase A (PKA), modulated by dopamine and cAMP-regulated phosphoprotein-32 (DARPP-32) (Flores-Hernandez et al., 2002), but the molecular mechanism by which $D_{1}$ activation potentiates NMDA receptor function has not been clearly identified.

Recent studies have emphasized the importance of intracellular trafficking and synaptic clustering of NMDA receptor subunits as mechanisms to mediate synaptic plasticity (Grosshans et al., 2002; Wenthold et al., 2003; Snyder et al., 2005). Functional NMDA receptors are believed to be tetrameric complexes of NR1 and NR2 subunits (Dingeldine et al., 1999; Wenthold et al., 2003). In the adult rat and human striatum, NR1, NR2A, and 
NR2B are the predominant subunits (Standaert et al., 1994; Kosinski et al., 1998; Dunah et al., 2004). Three distinct components of NMDA receptor trafficking have been identified, each with their own regulatory features: (1) synthesis and assembly of receptor subunits within the endoplasmic reticulum; (2) packaging and delivery of vesicles containing assembled receptors to spines; and (3) insertion of receptor complexes into synaptic sites (Carroll and Zukin, 2002; Wenthold et al., 2003; Dunah et al., 2004).

In this study, we show that, in striatal neurons, dopamine $\mathrm{D}_{1}$ receptor activation leads specifically to the trafficking and increased surface expression of NR2B-containing receptors. In contrast, inhibition of tyrosine phosphatases produces trafficking of both NR2A- and NR2B-containing receptors. These results demonstrate that activation of the dopamine $\mathrm{D}_{1}$ receptors potentiates striatal NMDA receptor function by directly promoting insertion of the subunits into the surface membrane.

\section{Materials and Methods}

Antibodies. Affinity-purified mouse anti-NR2B (Wang et al., 1995) and guinea pig anti-postsynaptic density-95 (PSD-95) (Wyszynski et al., 2002) antibodies were described previously. The following antibodies were obtained from commercial sources: mouse anti-NR1 antibody 54.1 (PharMingen, San Diego, CA); rabbit polyclonal anti-NR2A (Covance Research Products, Berkeley, CA); rabbit polyclonal N-terminus antiNR2B (Zymed, San Francisco, CA); GABA $_{A}$ receptor $\beta 2 / 3$ subunit (Chemicon, Temecula, CA); mouse anti-phosphotyrosine (PY20) and $\mathrm{N}$-cadherin (Transduction Laboratories, Lexington, KY); rabbit antiphosphotyrosine (PY20) (Upstate Biotechnology, Lake Placid, NY); rabbit anti-NR2B subunit (phospho-Tyr1472) (Signet Laboratories, Dedham, MA); rabbit anti-NR2B subunit (phospho-Tyr1472) (Imgenex, Sorrento Valley, CA); rabbit anti-dopamine $\mathrm{D}_{1}$ receptor (Calbiochem, La Jolla, CA); rabbit anti-dopamine $\mathrm{D}_{2}$ receptor (Santa Cruz Biotechnology, Santa Cruz, CA); Alexa Fluor 488-conjugated secondary antibodies (Invitrogen, Carlsbad, CA); and cyanine 3 (Cy3)-conjugated secondary antibodies (Jackson ImmunoResearch, West Grove, PA). The pharmacological agents used for treatment of striatal neurons were purchased from the following sources: genistein (Calbiochem); sodium orthovanadate (Acros Organics, Fairlawn, NJ); and hydrogen peroxide (Fisher Scientific, Pittsburgh, PA).

Neuron cultures and transfection. Primary striatal cultures were prepared from embryonic day 18 rat brains as described previously (Goslin and Banker, 1991). Cells were plated on coverslips coated with poly-Dlysine $(30 \mu \mathrm{g} / \mathrm{ml})$ and laminin $(2 \mu \mathrm{g} / \mathrm{ml})$ at a density of 100,000 per well. Striatal cultures were grown in Neurobasal medium (Invitrogen) and supplemented with B27 (Invitrogen), $0.5 \mathrm{~mm}$ glutamine, and $12.5 \mu \mathrm{M}$ glutamate. At $21 \mathrm{~d}$ in vitro (DIV21), striatal neurons were used for the described studies.

Pharmacological treatments of striatal neurons. The striatal neurons at DIV21 were treated with pervanadate (sodium orthovanadate) $(200 \mu \mathrm{M})$ or genistein $(50 \mu \mathrm{M})$ in dimethylsulfoxide (DMSO) for the time periods of 10 or $30 \mathrm{~min}$ at $37^{\circ} \mathrm{C}$ in the incubator. A stock solution of the pervanadate was prepared as described previously (Dunah et al., 1998). Striatal neurons at DIV21 were also treated for $10 \mathrm{~min}$ with the following pharmacological agents: the dopamine $\mathrm{D}_{1}$ receptor agonist SKF-82958 (2,3,4,5,tetrahydro-6-chloro-7,8-dihydroxy-1-phenyl-1 H-3-benz-azepine hydrobromide) $(50 \mu \mathrm{M})$; the dopamine $\mathrm{D}_{2}$ receptor agonist quinpirole (100 $\mu \mathrm{M})$; SKF-82958 (50 $\mu \mathrm{M})$ in the presence of the dopamine $\mathrm{D}_{1}$ receptor antagonist SCH23390 $[R(+)$-7-chloro-8-hydroxy-3-methyl-1-phenyl2,3,4,5-tetrahydro- $1 \mathrm{H}$-3-benzazepine hydrochloride] (5 $\mu \mathrm{M})$; and SKF$82958(50 \mu \mathrm{M})$ in the presence of genistein $(50 \mu \mathrm{M})$. For control, DMSO was added to a group of cells and subjected to the same conditions. The treated striatal neurons were harvested and applied for biochemical experiments, surface labeling, or fixed and used for immunocytochemical studies.

Immunocytochemistry of striatal neurons. For endogenous protein staining, striatal neurons were fixed with $4 \%$ paraformaldehyde and $4 \%$ sucrose at room temperature or in $100 \%$ methanol at $-20^{\circ} \mathrm{C}$ for $10 \mathrm{~min}$, washed in PBS three times for $5 \mathrm{~min}$ at room temperature, and incubated with primary antibodies in staining buffer (GDB buffer: $30 \mathrm{~mm}$ phosphate buffer, $\mathrm{pH} 7.4$, containing $0.2 \%$ gelatin, $0.5 \%$ Triton $\mathrm{X}-100$, and $0.8 \mathrm{M} \mathrm{NaCl}$ ) overnight at $4^{\circ} \mathrm{C}$. Cells were then washed three times in PBS for $10 \mathrm{~min}$ at room temperature. Cells were incubated with secondary antibody in GDB buffer for $1 \mathrm{~h}$ at room temperature, washed three times in PBS for $10 \mathrm{~min}$, and visualized with Alexa Fluor 488-conjugated secondary antibody. PSD-95 was stained with anti-PSD-95 antibodies and visualized with Cy3-conjugated secondary antibody.

Surface labeling of striatal neurons. Surface staining of endogenous NR2B subunit of NMDA receptors was performed as described previously (Wyszynski et al., 2002) with minor modifications using antibodies recognizing extracellular regions of NMDA receptor subunit NR2B (Zymed) and $\beta 2 / 3$ subunit of $\mathrm{GABA}_{\mathrm{A}}$ receptor (Chemicon). Briefly, striatal neurons were prefixed in $1 \%$ paraformaldehyde $/ 4 \%$ sucrose at room temperature for $3 \mathrm{~min}$, washed three times in PBS buffer, and incubated with primary antibodies $(20 \mu \mathrm{g} / \mathrm{ml})$ in GDB buffer under nonpermeabilizing conditions for $2 \mathrm{~h}$ at room temperature. Cells were then washed three times in PBS and incubated with secondary antibody in GDB buffer nonpermeabilizing conditions for $1 \mathrm{~h}$, washed three times, and visualized with Alexa Fluor 488-conjugated secondary antibody.

Surface biotinylation assay. High-density striatal neurons at DIV21 were used for surface biotinylation as described previously (Lin et al., 2000). Neurons treated with the pharmacological agents described above were washed three times with ice-cold PBS-plus (PBS containing $2.5 \mathrm{~mm}$ $\mathrm{CaCl}_{2}$ and $1 \mathrm{mM} \mathrm{MgCl}_{2}$ at $\mathrm{pH} 7.4$ ), and proteins on the surface of the neurons were biotinylated with $600 \mu \mathrm{g} / \mathrm{ml}$ Sulfo-NHS-SS-Biotin (Pierce, Rockford, IL) in PBS-plus for $20 \mathrm{~min}$ at $4^{\circ} \mathrm{C}$. Unreacted Sulfo-NHS-SSBiotin was removed by washing with ice-cold $50 \mathrm{~mm}$ glycine/PBS-plus three times and with ice-cold PBS. Cells were lysed with ice-cold lysis buffer (20 mm sodium phosphate, pH 7.5, $150 \mathrm{~mm} \mathrm{NaCl}, 0.1 \%$ SDS, $0.5 \%$ $\mathrm{NP}-40$, and $0.5 \%$ sodium deoxycholate) containing protease inhibitors ( $1 \mu \mathrm{g} / \mathrm{ml}$ aprotinin, $1 \mu \mathrm{g} / \mathrm{ml}$ leupeptin, and $1 \mathrm{~mm}$ PMSF). Biotinylated surface proteins were isolated using immobilized NeurtrAvidine beads (Pierce) and immunoblotted using antibodies against NR1, NR2A, NR2B, PSD-95, N-cadherin, and phosphotyrosine proteins.

Fluorescence lifetime imaging microscopy. Striatal neurons at DIV21 were treated with pervanadate as described above, fixed, and double immunostained for total phosphotyrosine proteins (PY20) and the NR2B subunit C-terminus antibody (Wang et al., 1995) to label total receptors. Fluorescence lifetime imaging microscopy (FLIM) was performed as described previously (Bacskai et al., 2003; Berezovska et al., 2003). In each experiment, negative controls consisted of neurons immunostained with the donor fluorophore (Alexa Fluor 488). A modelocked titanium-sapphire laser (Spectra-Physics, Fremont, CA) was used to generate a $100 \mathrm{fs}$ pulse every $12 \mathrm{~ns}$ to excite the fluorophore. Images were acquired using a Bio-Rad (Hercules, CA) Radiance 2000 multiphoton microscope. A high-speed Hamamatsu (Shizouka, Japan) MCP5900 detector and hardware/software from Becker and Hickl (Berlin, Germany) was used to measure fluorescence lifetime on a pixel-by-pixel basis. Excitation at $800 \mathrm{~nm}$ was empirically determined to excite Alexa Fluor 488 but not Cy3. Donor fluorophor lifetimes were analyzed with MetaMorph image analysis software (Universal Imaging Corporation, West Chester, CA) (see below) to calculate within each pixel the interaction with the acceptor fluorophor. Statistical testing was performed by Student's $t$ test by Bonferroni's post hoc correction.

Image analysis and quantification. Confocal images of single- and double-stained neurons were obtained using a Leica (Nussloch, Germany) $63 \times$ (numerical aperture 1.4) objective with sequential acquisition settings at the resolution of $1024 \times 1024$ pixels. Each image was a $z$-series of $8-10$ images spaced at intervals of $\sim 0.5 \mu \mathrm{m}$, and the resultant stack was "flattened" into a single image using a maximum projection. The confocal microscope settings were kept the same for all scans. All analysis and quantifications were performed using MetaMorph image analysis software. Dendrites from treated and control (untreated) cells were randomly selected and carefully traced, and the average intensity of fluorescence staining was then determined for the traced regions or the number of NMDA receptor subunit puncta that colocalized with PSD-95 clusters measured for the traced regions. Intensity measurements are 
expressed in arbitrary units of fluorescence per square area. Blind conditions were used for the acquisition and quantification of images.

Immunoblotting and immunoprecipitation. Homogenates from intact rat striatum or cultured striatal neurons at DIV21 were prepared and immunoblotted as described previously (Dunah et al., 2000). For tyrosine phosphorylation studies, rat striatum and cultured striatal neuronal homogenates were solubilized and denatured by boiling for $5 \mathrm{~min}$ in $1 \%$ SDS/TEVP buffer (10 mm Tris-HCl, pH 7.4, $5 \mathrm{~mm} \mathrm{NaF}, 1 \mathrm{~mm} \mathrm{NaVO}_{4}$, 50 mm dithiothreitol, 1 mM EDTA, 1 mm EGTA) and precipitated with anti-phosphotyrosine (PY20) antibody as described previously (Dunah et al., 1998).

\section{Results}

NMDA receptor subunit expression in cultured striatal neurons recapitulates the pattern in adult striatum

We characterized our cells in culture by staining for DARPP-32, a phosphoprotein that is highly expressed in the medium spiny projection neurons that constitute $>90 \%$ of striatal cells. The majority $(>80 \%)$ of the cells were immunopositive for DARPP-32 (data not shown). We further assayed for dendritic spines in the cultured striatal neurons by overexpressing green fluorescent protein to outline neuronal morphology. We observed a moderate number of dendritic spines in most DARPP32-immunopositive cells (supplemental Fig. $1 \mathrm{~A}$, available at www. jneurosci.org as supplemental material). The dopamine $\mathrm{D}_{1}$ and $\mathrm{D}_{2}$ receptors are also expressed in the cultured neurons; these proteins have a punctate somatodendritic distribution (supplemental Fig. $1 B, C$, available at www.jneurosci.org as supplemental material), as noted by others (Day et al., 2006; Falk et al., 2006). Each of the $D_{1}$ and $D_{2}$ receptors is expressed by most of the neurons present in our primary striatal cultures, which differs from the segregation of these receptors observed in the intact adult striatum (Hersch et al., 1995; Smith and Kieval, 2000).

The expression of NMDA receptor subunits in cultured striatal neurons at DIV21 was compared with that in adult rat striatum (Fig. $1 A$ ). Based on immunoblotting with antibodies specific for the NMDA subunits, NR1, NR2A, and NR2B proteins are enriched in both the intact striatum and cultured striatal neurons (Fig. 1A). PSD-95, a scaffolding protein for the postsynaptic density that binds to the NMDA class of glutamate receptors, is also abundant in both striatal tissue and striatal neurons (Fig. $1 A$ ). In striatal neurons in low-density culture at DIV21, the NR1, NR2A, and NR2B proteins and PSD-95 exhibited immunostaining patterns characterized by fine and bright puncta along dendrites (Fig. $1 B$ ). Some of these puncta appeared to be associated with dendritic spines, but many appeared to be localized along the shafts of dendrites. Clusters of the NMDA receptor subunits were also seen in cell bodies. These patterns are compatible with previous light microscopic and ultrastructural studies of NMDA receptors in the brain (Petralia et al., 1994).

\section{Cultured striatal neurons exhibit progressive clustering of NMDA receptor subunits with components of the postsynaptic density}

Biochemical studies in rat brain have shown that the expression of NR2A subunit in striatal neurons is low at birth, first becomes apparent at postnatal day 7 , and increases in abundance as the brain matures. In contrast, NR2B is highly expressed at birth, remains sustained during postnatal development, and declines at adulthood. NR1 subunit expression is relatively high at birth and is sustained during development and at adulthood (Monyer et al., 1994; Sheng et al., 1994; Wang et al., 1995; Sans et al., 2000). We investigated the expression and localization of NMDA receptors in striatal neurons in culture at different ages by costaining the
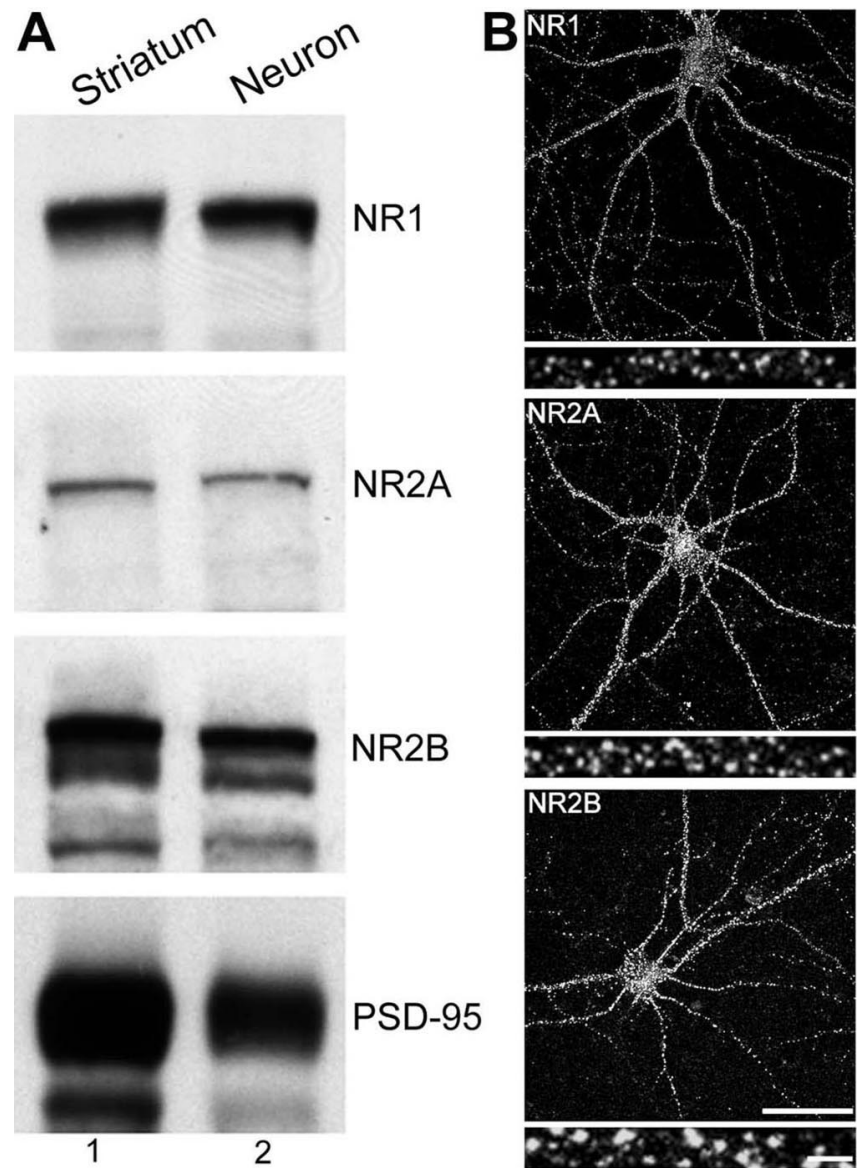

Figure 1. Expression of NMDA receptor subunits in cultured striatal neurons. $A$, Expression of subunits of NMDA receptors in striatal neurons. Total homogenates (10 $\mu \mathrm{g}$ of protein) from rat striatum (lane 1) and mature (DIV21) striatal neurons (lane 2) were subjected to SDS-PAGE and probed for NR1, NR2A, NR2B, and PSD-95 proteins. $B$, Localization of NMDA receptor subunits in striatal neurons. Striatal neurons in dissociated culture at DIV21 were labeled for endogenous NR1, NR2A, and NR2B subunits. Higher magnifications of individual dendritic segments are shown below each panel. Scale bars: top panels, $80 \mu \mathrm{m}$; higher-magnification panels, $8 \mu \mathrm{m}$.

various subunits with an antibody against PSD-95, a postsynaptic density marker (supplemental Fig. 2, available at www.jneurosci. org as supplemental material). At DIV7, NR1, NR2A, and NR2B antibodies showed fine punctate immunostaining in cell bodies and dendritic shafts of striatal neurons (supplemental Fig. 2a,d,g, available at www.jneurosci.org as supplemental material). The NMDA receptor clusters showed only partial colocalization with PSD-95 puncta at DIV7 (supplemental Fig. $2 a, d, g$, available at www.jneurosci.org as supplemental material). At DIV14 (supplemental Fig. 2b,e, $h$, available at www.jneurosci.org as supplemental material) and DIV21 (supplemental Fig. $2 c, f, i$, available at www.jneurosci.org as supplemental material), the clusters for NR1, NR2A, and NR2B subunits were more concentrated along dendrites and exhibited more extensive colocalization with PSD95. Thus, there was a progression of NMDA receptor clusters with neuronal maturation, with increasing concentration of subunits together with components of the postsynaptic density.

Tyrosine phosphorylation of NMDA receptor subunits in cultured striatal neurons is regulated by tonically active phosphatase activity

Protein phosphorylation is an important regulatory mechanism of glutamate receptor function in the CNS. NMDA receptors have been shown to be phosphorylated at tyrosine residues in the 

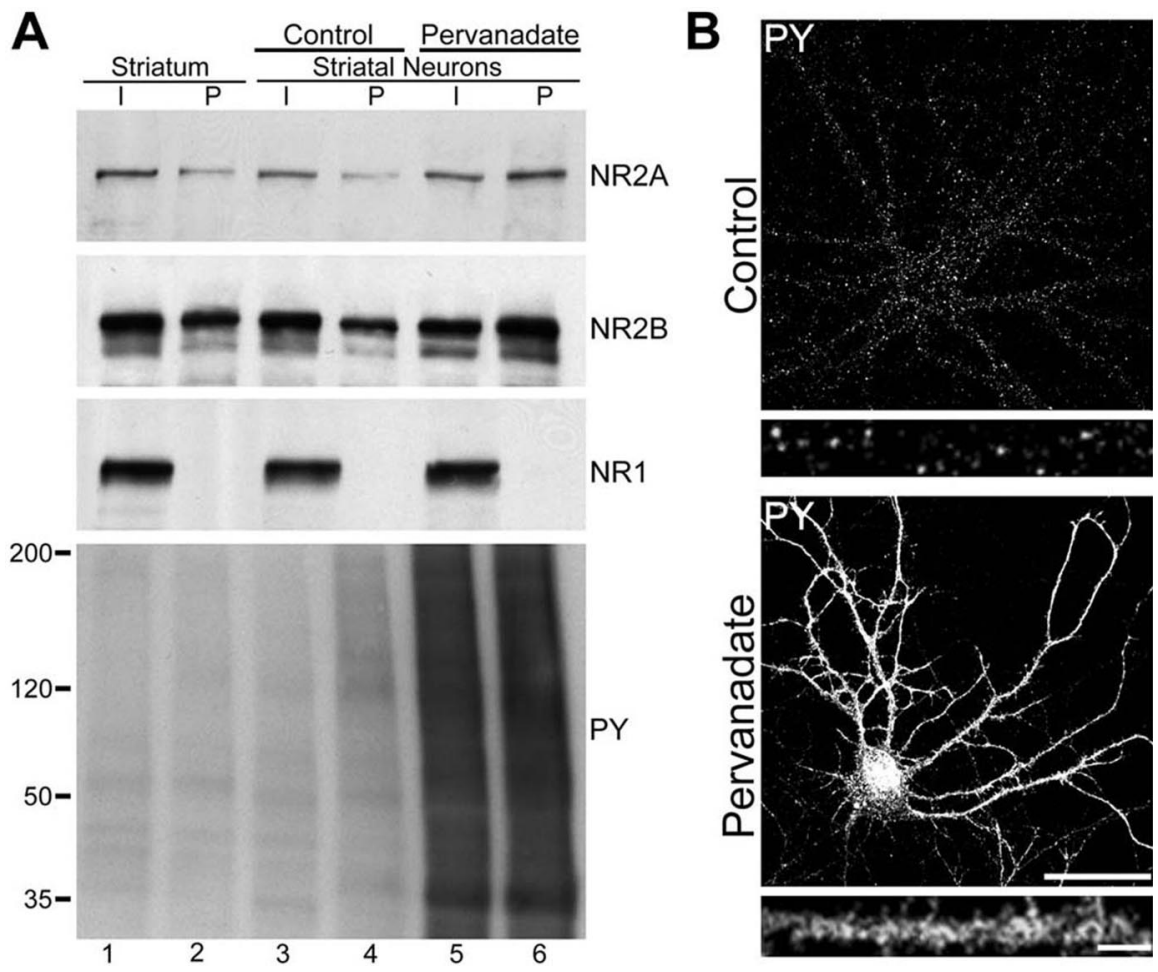

Figure 2. Tyrosine phosphorylation of NMDA receptor subunits in striatal neurons. $\boldsymbol{A}$, Tyrosine-phosphorylated NR2A and NR2B subunits in striatal neurons. SDS extracts of rat striatum and control (untreated; lanes 3,4 ) or pervanadate-treated (lanes 5 , 6) striatal neurons in culture at DIV21 were immunoprecipitated with anti-phosphotyrosine antibody (PY20). The input (lanes 1, $3,5$ ) and precipitates ( $P$; lanes $2,4,6)$ were immunoblotted for the NR2A, NR2B, and NR1 subunits and phosphotyrosine (PY) proteins as indicated. $\boldsymbol{B}$, Control (untreated, top) and striatal neurons at DIV21 treated with pervanadate (bottom) were stained for endogenous phosphotyrosine proteins (PY). Higher magnifications of individual dendritic segments are shown below each panel. Scale bars: top panels, $80 \mu \mathrm{m}$; higher-magnification panels, $8 \mu \mathrm{m}$.

brain (Lau and Huganir, 1995; Rosenblum et al., 1996; Dunah et al., 1998). In striatal tissues, inhibition of endogenous tyrosine phosphatases leads to a striking enhancement of phosphorylation of NMDA receptor subunits, demonstrating the importance of phosphatases in maintaining homeostasis (Dunah et al., 1998; Dunah and Standaert, 2001).

To study tyrosine-phosphorylated NMDA receptors in cultured striatal neurons, denatured protein extracts from adult rat striatum (Fig. $2 A$, lanes 1,2 ) and striatal neurons (Fig. $2 A$, lanes $3,4)$ were precipitated with anti-phosphotyrosine antibody and immunoblotted for NR2A, NR2B, and NR1 subunits, as well as for total phosphotyrosine proteins (Fig. 2A, PY). Consistent with previous reports (Dunah et al., 2000), the NR2A and NR2B subunits, but not the NR1 subunit, were tyrosine phosphorylated in the extracts of striatal tissue (Fig. $2 \mathrm{~A}$, lane 2). Tyrosine phosphorylation of NR2A and NR2B, but not NR1, was also detected in striatal neurons (Fig. $2 \mathrm{~A}$, lane 4 ) but to a lesser extent than that in the tissues (Fig. 2A, compare lanes 2, 4). Thus, the tyrosine phosphorylation of NMDA receptor subunits NR2A and NR2B in cultured neurons closely resembles that of adult striatum under nonstimulated conditions.

To test whether interfering with the activity of protein tyrosine phosphatases in cultured striatal neurons might alter the tyrosine phosphorylation levels of NMDA receptors, we treated mature striatal neurons (DIV21) in culture for $30 \mathrm{~min}$ with pervanadate (a protein tyrosine phosphatase inhibitor) (Fig. 2A). Extracts of treated and control (untreated) striatal neurons were precipitated with anti-phosphotyrosine antibody and probed for NR2A, NR2B, NR1, and total phosphotyrosine proteins (Fig. 2A, lanes 3-6, PY). Compared with control cells, pervanadate-treated cells exhibited a robust increase in tyrosine phosphorylation of NR2A and NR2B subunits (Fig. $2 \mathrm{~A}$, compare lanes 4,6 ), and a drastic enhancement in the levels of total phosphotyrosine proteins that could be observed by both immunoprecipitation and staining neurons with an anti-phosphotyrosine antibody (Fig. 2A, PY, compare lanes 4 and 6, $B)$. These results demonstrate that the NMDA receptor NR2A and NR2B subunits are tyrosine phosphorylated in cultured striatal neurons and strongly regulated by tonically active protein tyrosine phosphatases. Tyrosine phosphorylation regulates the
targeting and localization of NMDA
receptor subunits
Modifications in tyrosine phosphorylation of the NR2 subunits of NMDA receptors have been observed in several models of synaptic plasticity (Rostas et al., 1996) as well as in animal models of Parkinson's disease after treatment with dopaminergic agents (Menegoz et al., 1996; Oh et al., 1998; Dunah et al., 2000). Taking advantage of the striking effect of inhibition of protein tyrosine phosphatase activity on the tyrosine phosphorylation of NMDA receptors (Fig. 2), we investigated whether the targeting and localization of subunits of NMDA receptors in striatal neurons is regulated by their phosphorylation states. We applied pervanadate, a tyrosine phosphatase inhibitor, or genistein, a tyrosine kinase blocker, to mature striatal neurons (DIV21) in culture for 10 or $30 \mathrm{~min}$ and double labeled the cells for NR1, NR2A, or NR2B, and PSD-95 (Fig. 3). We used quantitative morphometric analysis (Wyszynski et al., 2002; Dunah et al., 2005) to measure the intensity of staining in neuronal dendrites and the density of stained clusters along dendrites.

After 10 min of pervanadate treatment, the staining intensity of NR2A subunits in neuronal dendrites was significantly increased, whereas a longer duration of treatment $(30 \mathrm{~min})$ resulted in marked enhancement in the dendritic staining for NR1, NR2A, and NR2B (Figs. 3, 4A). In contrast, treatment of striatal neurons with the tyrosine kinase inhibitor genistein exhibited a general trend for reduction in the immunofluorescence staining intensities of NR1, NR2A, and NR2B; this effect was statistically significant for NR1 at both time points examined and for NR2A at 30 $\min$.

We assayed the targeting of NMDA receptors to postsynaptic sites by measuring the intensity of NMDA subunit staining in dendritic regions defined by the presence of PSD-95-positive clusters (Fig. 3, quantified in Fig. 4B). Treatment with pervanadate markedly enhanced the association of NR1, NR2A, and NR2B subunits with PSD-95 clusters at both of the time points studied (Figs. 3, 4B). In contrast, genistein appeared to decrease the targeting of NMDA subunits to sites containing PSD-95, an effect that was statistically significant for NR1 at both time points and for NR2B at 30 min (Figs. 3, 4B). These results demonstrate that tyrosine phosphatases and kinases reciprocally modulate the 
localization of NMDA receptors in striatal neurons and the clustering of subunits with PSD-95.

Tyrosine phosphorylation promotes the insertion of NMDA receptor subunits into plasma membranes

Increased glutamate receptor activity requires not only the clustering of receptors together with elements of the postsynaptic density but also incorporation into the plasma membrane so that the ligand binding domains are accessible to the extracellular environment. Thus, to directly measure the effect of pervanadate or genistein on the surface expression of NMDA receptors, striatal neurons at DIV21 treated with these pharmacological agents were labeled with antibodies against the extracellular region of NR2B (Zymed) (Fig. 5A). Specificity of the N-terminus polyclonal NR2B antibody for its cognate subunit was confirmed on immunoblots of COS-7 cells transfected with NR2B, cultured neurons, and rat brain tissues (data not shown). Unlike the studies described above, these experiments were performed in the absence of cell-permeabilizing agents to keep the plasma membrane intact. To confirm the integrity of the cell membranes under these conditions, we stained for PSD-95 using the same approach and observed no detectable signal (data not shown).

Using this surface staining methods, untreated (control) cells stained under nonpermeabilizing conditions show surface staining for endogenous NR2B in a punctate pattern that is mostly confined to the dendrites, without detectable signal in the cell body (Fig. 5A, Control). This is quite different from the immunofluorescence staining pattern observed using permeabilizing conditions, in which NMDA receptor staining is observed in both dendrites and cell soma (Fig. $1 B$ ). Treatment with pervanadate strongly increased the surface labeling for NR2B on striatal neuronal dendrites, measured by either the total intensity of the signal or counting the number of NR2B puncta. Genistein, the tyrosine kinase inhibitor, produced the opposite effect (Fig. 5A-C).

Because efforts to identify antibodies that are capable of labeling surface NR1 and NR2A subunits were unsuccessful, and as a means of confirming the results obtained with the NR2B antibody, we used a surface biotinylation assay to study the effect of perturbing tyrosine phosphatase or tyrosine kinase activity on these subunits (Fig. 5D). Using this approach, we found that treatment of high-density cultured striatal neurons with pervanadate significantly increased the surface localization of all three NMDA receptor subunits relative to control, NR1 (156 $\pm 10 \%$; $p<0.01)$, NR2A $(144 \pm 8 \% ; p<0.01)$, and NR2B $(179 \pm 6 \%$;

Control
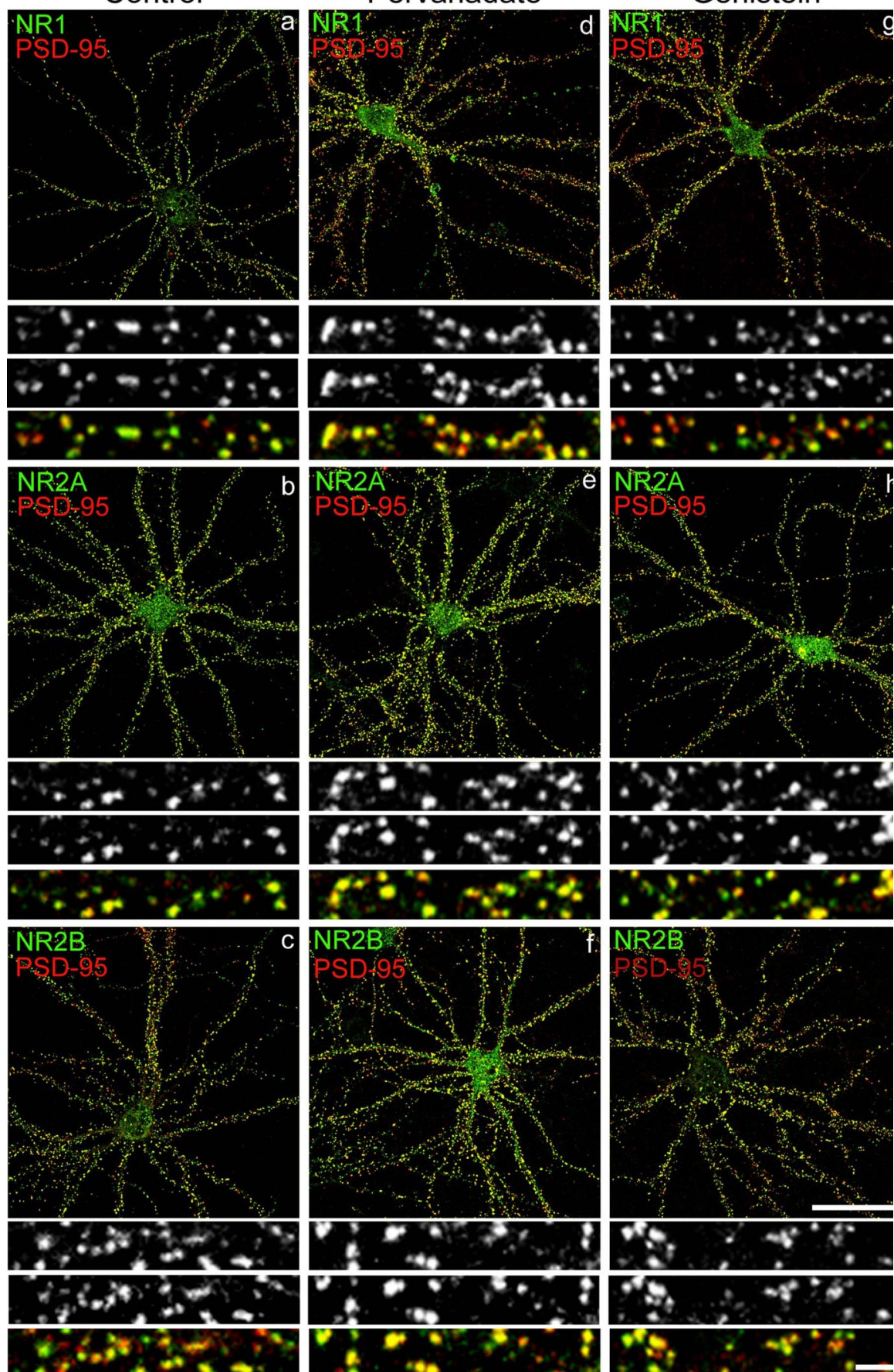

Figure 3. Inhibition of protein tyrosine phosphatases and tyrosine kinases modify the localization and clustering of NMDA receptor subunits. Control (untreated; $\boldsymbol{a}-\boldsymbol{c}$ ) and mature striatal neurons at DIV21 were treated with pervanadate $(\boldsymbol{d}-\boldsymbol{f})$ or genistein $(\boldsymbol{g}-\boldsymbol{i})$ and double labeled for endogenous NR1, NR2A, and NR2B (green) and PSD-95 (red). Higher-magnification panels show individual dendrite segments, in grayscale for NMDA receptor subunits (top), PSD-95 (middle), and in color for merged green and red channels (bottom). Scale bars: top panels, $80 \mu \mathrm{m}$; higher-magnification panels, $8 \mu \mathrm{m}$.

$p<0.001$ ) (Fig. 5D). Conversely, genistein reduced the surface levels of NR1 (81 $\pm 8 \%$; $p<0.05)$, NR2A $(73 \pm 9 \%$; $p<0.05)$, and NR2B $(61 \pm 6 \%$; $p<0.01)$ proteins (Fig. $5 D)$. Surface $\mathrm{N}$-cadherin (positive control), but not PSD-95 (negative control), was detected with this method, demonstrating specificity of the biotinylation assay (Fig. 5D). Thus, these data corroborate the results from immunohistochemical surface labeling experiments with the NR2B antibody and provide evidence that the surface 

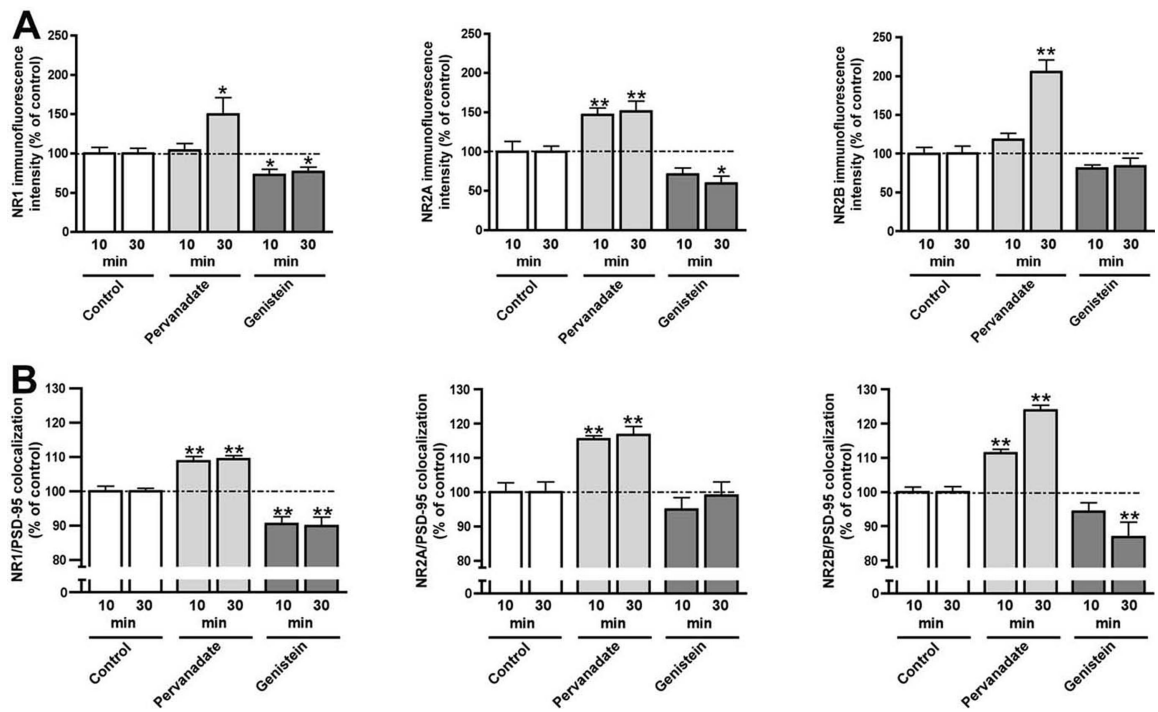

Figure 4. Quantitation of immunofluorescence staining intensity and colocalization of NMDA receptors with PSD-95 in pervanadate- and genistein-treated neurons. $\boldsymbol{A}, \boldsymbol{B}$, Histograms (mean $\pm \mathrm{SEM}$ ) show immunofluorescence staining intensity (arbitrary units of fluorescence per square area, $\boldsymbol{A}$ ), and clusters of NR1, NR2A, and NR2B that colocalized with PSD-95 puncta ( $\boldsymbol{B}$ ) in striatal neurons treated with pervanadate or genistein for time periods of 10 and 30 min (experiment depicted in Fig. 4) were analyzed as described in Materials and Methods. ${ }^{*} p<0.05 ;{ }^{* *} p<0.01$.
A

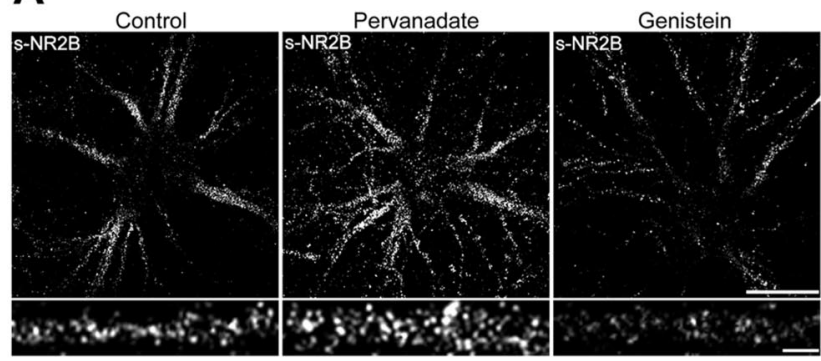

B

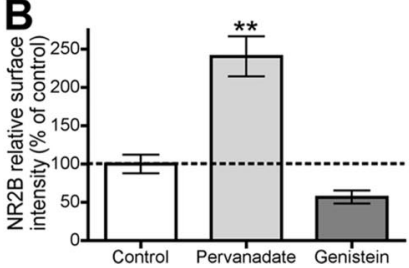

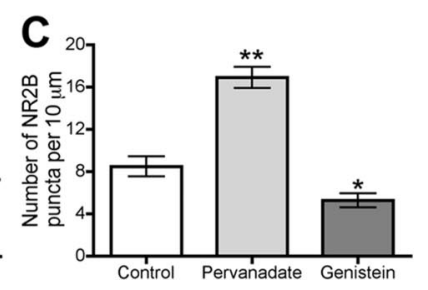

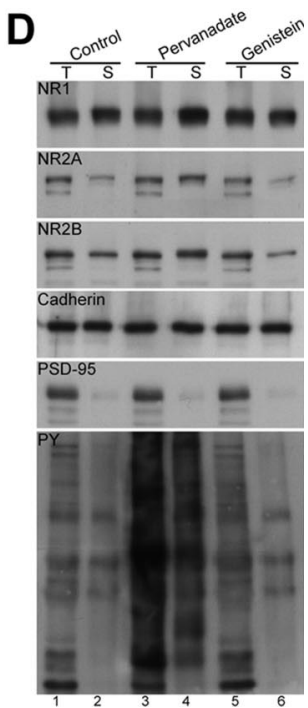

Figure 5. Inhibition of tyrosine phosphatase or tyrosine kinase activity alters the surface expression and targeting of striatal NMDA receptors. $\boldsymbol{A}$, Striatal neurons at DIV21 were treated with pervanadate or genistein for 30 min and labeled for endogenous surface NR2B (s-NR2B). Higher-magnification panels show individual dendrite segments in grayscale. Scale bars: top panels, 80 $\mu \mathrm{m}$; higher-magnification panels, $8 \mu \mathrm{m} . \boldsymbol{B}, C$, Quantitation of surface levels of endogenous NR2B in striatal neurons treated with pervanadate or genistein in $\boldsymbol{A}$. Histograms (mean \pm SEM) show surface immunofluorescence staining intensity (arbitrary units of fluorescence per square area) $(\boldsymbol{B})$ or number of puncta per $10 \mu \mathrm{m}(\boldsymbol{C})$ of NR2B. ${ }^{*} p<0.05$; ${ }^{* *} p<0.01$. D, Surface biotinylation of NMDA receptors in high-density striatal neuron culture at DIV21 treated with pervanadate or genistein. The biotinylated proteins were purified, and both the total/input $(\mathrm{T})$ and surface/biotinylated $(\mathrm{S})$ proteins were resolved on SDS-PAGE and immunoblotted for NR1, NR2A, NR2B, N-cadherin (cadherin), PSD-95, and total phosphotyrosine proteins (PY).

expression of NR1, NR2A, and NR2B are each modified by protein phosphatase inhibition.

Nonetheless, these results imply that tyrosine phosphorylation not only regulates the targeting and clustering of NMDA receptors but also their insertion into the plasma membrane. The effect of pervanadate or genistein on the surface expression of these subunits seems to be relatively specific for the NMDA receptors because surface $\mathrm{GABA}_{\mathrm{A}}$ receptors (assayed with antibodies directed against the extracellular domain of the $\beta 2 / 3$ subunits) were not altered by any of these pharmacological interventions (data not shown).

Dopamine $D_{1}$ receptor activation selectively regulates targeting and clustering of the NR2B subunit in cultured striatal neurons

We treated striatal neurons at DIV21 with the specific dopamine $D_{1}$ receptor agonist SKF-82958 $(50 \mu \mathrm{m})$ for $10 \mathrm{~min}$ (Fig. 6) and assessed the effect on localization, targeting, and clustering of receptor subunits.

Using immunohistochemical staining of neurons under permeabilizing conditions, we found that treatment with SKF82958 markedly increased the intensity of staining for NR2B in the dendrites of striatal neurons (Fig. 6) and the colocalization of NR2B with PSD-95-positive clusters $(127 \pm 6 \% ; p<0.01)$ compared with control. Interestingly, the effect on NR1 intensity (Fig. 6) and colocalization with PSD-95 (116 $\pm 4 \% ; p<0.05)$ was less, and the $\mathrm{D}_{1}$ agonist had no effect on the intensity (Fig. 6) or colocalization of NR2A with PSD-95 (NR2A, $104 \pm 7 \%$ ). Using the assay for surface receptors, performed under nonpermeabilizing conditions, we observed a similar striking enhancement of surface NR2B receptor proteins after stimulation with SKF-82958 (Fig. 7A). Compared with the control, treatment with SKF-82958 significantly increased both the surface signal intensity $(183 \pm 15 \%$; $p<0.001)$ and the number of clusters $(240 \pm 14.8 \% ; p<0.0001)$ of the NR2B subunit. Analysis of data from individual neurons demonstrated that $\mathrm{D}_{1}$ stimulation increased the surface expression in the majority of the neurons present (supplemental Fig. 1D, available at www. jneurosci.org as supplemental material), consistent with our observation that most of the neurons in this culture system express the $\mathrm{D}_{1}$ receptor protein. We also confirmed these results using the surface biotinylation assay, which again demonstrated selective enhancement of surface NR2B $(182 \pm 6 \% ; p<0.001)$ and NR1 $(146 \pm$ $4 \% ; p<0.01)$ relative to control by the $\mathrm{D}_{1}$ agonist, without any effect on the NR2A subunit $(116 \pm 7 \% ; p>0.30)$. In these assays, treatment with quinpirole, a specific dopamine $\mathrm{D}_{2}$ receptor agonist (100 $\mu \mathrm{M})$, showed no detectable effect on the staining intensity or targeting of any of the NMDA subunits (Fig. $7 B$ ). Moreover, the SKF-82958-mediated increase in dendritic staining intensity and targeting of the NR2B subunit was blocked when neurons were pretreated with either genistein (tyrosine kinase inhibitor) or with $\mathrm{SCH} 23390$, a selective $\mathrm{D}_{1}$ receptor antagonist (Figs. $6 A, D$, 7B).

These results demonstrate that dopamine $\mathrm{D}_{1}$ receptor activation produces a rapid trafficking of NMDA receptors containing 
the NR2B subunit, with increases in both the total amount of protein present within dendrites and increased insertion into the plasma membrane. The ability of genistein to block the process suggests a requirement for a tyrosine kinase in this process. The effect of dopamine $\mathrm{D}_{1}$ activation, however, differs from the nonselective inhibition of tyrosine kinases produced by pervanadate in that it enhances surface NR2B and to a lesser extent NR1, whereas nonselective tyrosine kinase inhibition increases surface signals for NR1, NR2A, and NR2B subunits.

Tyrosine-phosphorylated NR2B protein is clustered in the dendritic shafts

The NR2B subunit is the predominant phosphotyrosine protein in the postsynaptic density (Kennedy, 1997), and its carboxy tail constitutes a potential substrate for tyrosine phosphorylation-mediated modulation of NMDA receptor function. Because the major site for phosphorylation of NR2B has been identified to be Tyr1472, which is a substrate for Fyn tyrosine kinase (Moon et al., 1994; Suzuki and Okumura-Noji, 1995; Nakazawa et al., 2001), we investigated whether stimulation of the dopamine $\mathrm{D}_{1}$ receptor modifies the phosphorylation of this tyrosine residue. Striatal neurons at DIV21 were treated with specific dopamine $\mathrm{D}_{1}$ receptor agonist as above and stained with NR2B antibody against the tyrosine 1472 residue (Fig. $7 C$ ). We observed punctate staining in the dendrites and cell soma (Fig. 7C). Compared with control cells, treatment with SKF-82958 increased the signal intensity of phosphotyrosine 1472 of NR2B (NR2BTyr1472) subunit $(152 \pm 6 \% ; p<0.001)$, and this effect was further confirmed by immunoblotting (Fig. 7D). A similar increase in the intensity of phosphorylation of NR2B at tyrosine 1472 was also seen in pervanadate-treated striatal neurons (data not shown).

To confirm the localization of tyrosine-phosphorylated NR2B subunit in intact cells, we applied FLIM, a fluorescence resonance energy transfer (FRET)-based approach to detect protein-protein interactions (Fig. $8 A$, quantified in $B$ ). Untreated and pervanadate-treated striatal neurons at DIV21 were double immunostained under permeabilizing conditions for the NR2B subunit using an antibody to the C terminus (Wang et al., 1995) and for phosphotyrosine proteins with the anti-phosphotyrosine antibody; the donor fluorophore (NR2B) was labeled with Alexa Fluor 488 and the acceptor fluorophore (phosphotyrosine proteins) with $\mathrm{Cy} 3$. Proximity of the two fluorophores results in resonance energy transfer and shortens the fluorescence lifetime of the donor. We measured the donor lifetime in each image pixel using a pulsed laser and dual-photon confocal system. For negative controls, cells stained with only the donor fluorophore (Alexa Fluor 488) were used (Fig. $8 A a, A b$ ).

Using this approach, we detected robust staining for NR2B in both the soma and dendrites of neurons. In the untreated cells, only a small proportion of pixels exhibited a shortened donor lifetime, and these were concentrated along the dendritic regions (Fig. $8 A d, B$ ), indicating the presence of tyrosine-phosphorylated NR2B. Treatment of striatal neurons with the phosphatase inhibitor pervanadate markedly enhanced the number of pixels with a short fluorescent lifetime, indicating a large increase in the extent of tyrosine phosphorylation of the carboxy tail of NR2B. Quantitative analysis of the signals in both the soma and the dendrites revealed that tyrosine-phosphorylated NR2B was increased in both compartments, but the effect was more than six times greater in the dendrites than in the soma (Fig. $8 A f, B$ ). These data demonstrate a strong association between tyrosine phosphorylation of NR2B and dendritic localization of the receptor protein.

\section{Discussion}

\section{Dopamine $\mathrm{D}_{1}$ receptor-mediated trafficking of striatal} NMDA receptors

In our studies, we observed a selective effect of dopamine $D_{1}$ receptor activation on the localization of NMDA subunits in striatal neurons. Treatment with a $\mathrm{D}_{1}$, but not a $\mathrm{D}_{2}$, receptor agonist leads to increased dendritic localization and surface expression of NR2B subunit. Dopamine $D_{1}$ receptor activation induces tyrosine phosphorylation of NR2B and causes it to cocluster with PSD-95, a prerequisite for assembly of NMDA receptors at 
A

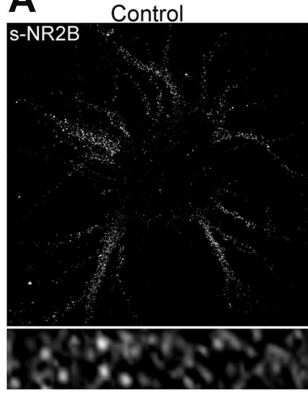

C
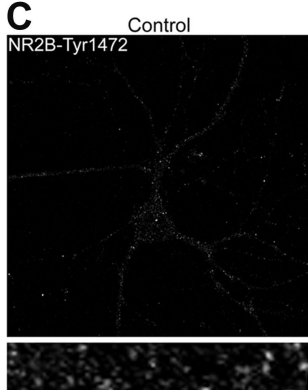
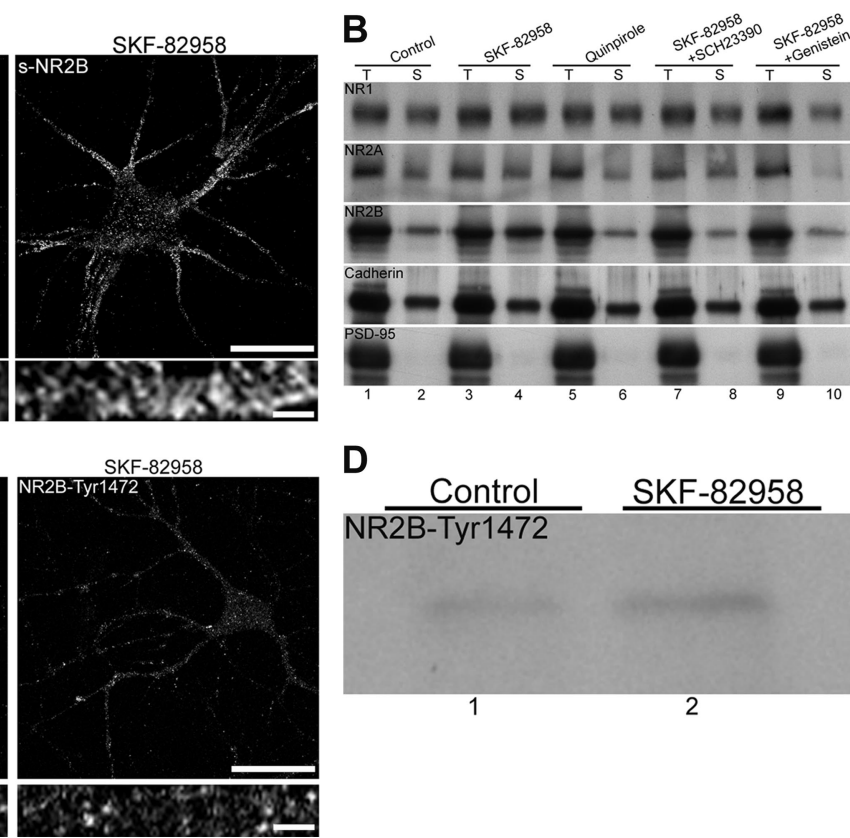

D

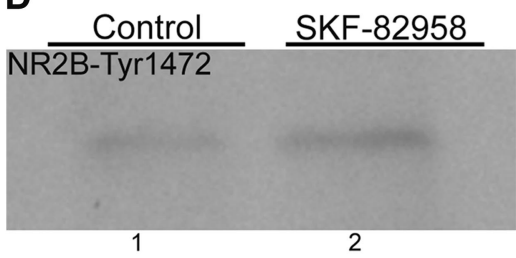

Figure 7. Dopamine $D_{1}$ receptor activation increases the surface expression and targeting of striatal NMDA receptors. $A$, Cultured striatal neurons at DIV21 were treated with the dopamine $D_{1}$ receptor agonist SKF-82958 and labeled for surface NR2B (s-NR2B). Higher-magnification panels show individual dendritic segments in grayscale. Scale bars: top panels, $80 \mu \mathrm{m}$; highermagnification panels, $8 \mu \mathrm{m}$. $\boldsymbol{B}$, Surface biotinylation of NMDA receptors in high-density striatal neurons at DIV21 treated with SKF-82958 (lanes 3, 4), quinpirole (lanes 5, 6), SKF-82958 plus SCH23390 (lanes 7, 8), and SKF-82958 plus genistein (lanes 9, 10). The biotinylated proteins were purified, and both the total/input ( $\mathrm{T}$ ) and surface/biotinylated $(\mathrm{S})$ proteins were resolved on SDS-PAGE and immunoblotted for NR1, NR2A, NR2B, N-cadherin (cadherin), and PSD-95. C, Striatal neurons at $21 \mathrm{~d}$ in vitro were treated with the $D_{1}$ receptor agonist SKF-82958 and stained for phosphorylation of NR2B at tyrosine 1472 (NR2B-Tyr1472) (Signet Laboratories). Higher-magnification panels show individual dendritic segments in grayscale. Scale bars: top panels, $80 \mu \mathrm{m}$; higher-magnification panels, $8 \mu \mathrm{m}$. D. Immunoreactivity of NR2B-Tyr1472 in striatal neurons. Striatal neurons at DIV21 were treated with SKF-82958, resolved on SDS-PAGE, and probed for NR2B-Tyr1472 (Imgenex).

postsynaptic densities. A modest increase in surface NR1 is also observed, consistent with the view that coassembly of NR1 and NR2 subunits is required for cell surface expression of NMDA receptors (McIlhinney et al., 1998; Wenthold et al., 2003).

Trafficking of NMDA receptors provides a mechanistic basis for the changes in function of striatal NMDA receptors that are observed after $\mathrm{D}_{1}$ receptor stimulation. In both striatal slice preparations and dissociated neurons, dopamine or selective $\mathrm{D}_{1}$ activation potentiates NMDA receptor currents (Cepeda et al., 1993, 1998; Levine et al., 1996; Flores-Hernandez et al., 2002). PKA and voltage-dependent $\mathrm{Ca}^{2+}$ conductances participate in this interaction (Cepeda et al., 1998; Flores-Hernandez et al., 2002). Studies of the effects of clozapine, which indirectly activates $D_{1}$ receptors, have implicated both PKA and the Src family of tyrosine kinases in NMDA receptor potentiation (Wittmann et al., 2005). The DARPP-32 signaling pathway has been implicated in the ability of $D_{1}$ receptor activation to potentiate NMDA currents, yet genetic deficiency of DARPP-32 reduces but does not eliminate NMDA receptor potentiation, pointing to the importance of DARPP-32-independent mechanisms (Flores-Hernandez et al., 2002). We have shown previously that, in intact striatal tissue, $\mathrm{D}_{1}$-dependent NMDA receptor redistribution is not altered by genetic deficiency of the DARPP-32 protein (Dunah et al., 2004).

Striatal projection neurons in vivo are densely studded with dendritic spines, in which PSD-95 and glutamate receptors are concentrated (Smith et al., 1994; Levine et al., 1996; Cepeda et al., 1998). In these studies, we used primary cultures of striatal neurons that lack cortical excitatory input, exhibit little spontaneous activity and form fewer spines than neurons in intact brain or corticostriatal culture (Segal et al., 2003). They also exhibit coexpression of $\mathrm{D}_{1}$ and $\mathrm{D}_{2}$ receptor proteins, which are primarily segregated in adult brain (Hersch et al., 1995; Smith and Kieval, 2000), and clustering of PSD-95 and NMDA receptors both within spines and along dendritic shafts. Our data suggest that, despite the less mature phenotype of cultured striatal neurons, they contain all of the mechanisms required for $\mathrm{D}_{1}$-dependent trafficking and surface localization of NMDA receptors and that these mechanisms reside within the postsynaptic structures. We observed that $\mathrm{D}_{1}$ activation increases the total intensity of the NMDA receptor staining in dendrites, suggesting trafficking from the somatic compartment into dendritic regions, and increases surface accessibility and colocalization of the subunits with PSD-95. Because we have not directly labeled individual subunits, we cannot exclude the alternative possibility that $\mathrm{D}_{1}$ activation reduces endocytosis and degradation of subunits rather than enhancing insertion into the membrane. It is possible that both types of effects are important.

\section{Role of tyrosine phosphorylation in striatal NMDA receptor trafficking} In cultured striatal neurons, inhibition of tyrosine phosphatases with pervanadate leads to dramatic alterations in NMDA subunit localization. In contrast to the effects of the $D_{1}$ receptor agonist, the effect of tyrosine phosphatase inhibition is nonselective and leads to increased NR1, NR2A, and NR2B in dendritic shafts. Tyrosine phosphatase inhibition also increases the surface expression of all three NMDA subunits and enhances their coclustering with PSD-95. Although pervanadate treatment likely alters the phosphorylation state of many cellular proteins, a prominent effect is enhanced phosphorylation of NR2A and NR2B subunits. Reciprocal effects are produced by the tyrosine kinase inhibitor genistein. These results demonstrate the pivotal role of tyrosine phosphorylation as a mechanism of regulating the synaptic localization and clustering of NMDA receptors in striatal neurons.

The drastic effects of tyrosine phosphatase inhibition on striatal NMDA receptor phosphorylation and distribution point to the importance of a tonically active tyrosine phosphatase in striatal neurons. A candidate for this role is the striatal enriched phosphatase (STEP), a protein tyrosine phosphatase that is expressed in striatal neurons and demonstrated to be present in a complex with NMDA receptors (Boulanger et al., 1995; Pelkey et al., 2002). This provides a potential mechanistic link between dopamine $D_{1}$ receptor activation and enhanced tyrosine phosphorylation, because STEP is inhibited by the action of PKA (Paul et al., 2000).

The NR2B subunit is a substrate of the tyrosine kinases and phosphatases regulating NMDA receptor trafficking Several lines of evidence suggest that a key substrate for the regulation of NMDA receptor trafficking by tyrosine phosphorylation is the carboxy tail of NR2B subunit, the most abundant 

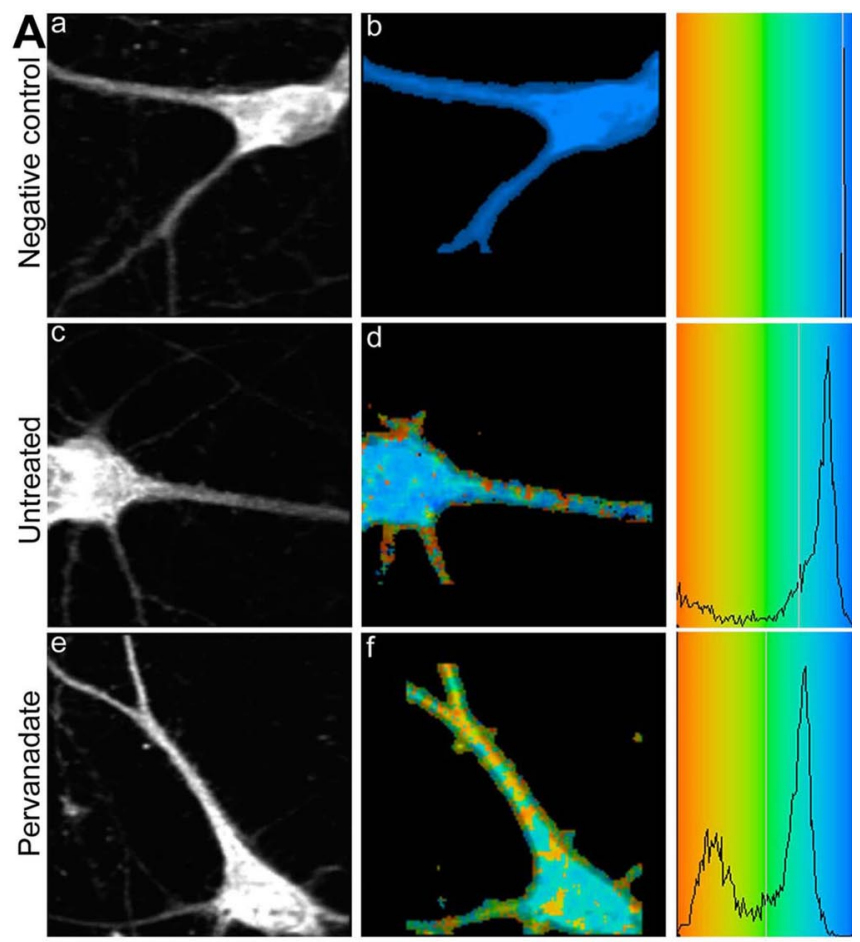

\section{B}

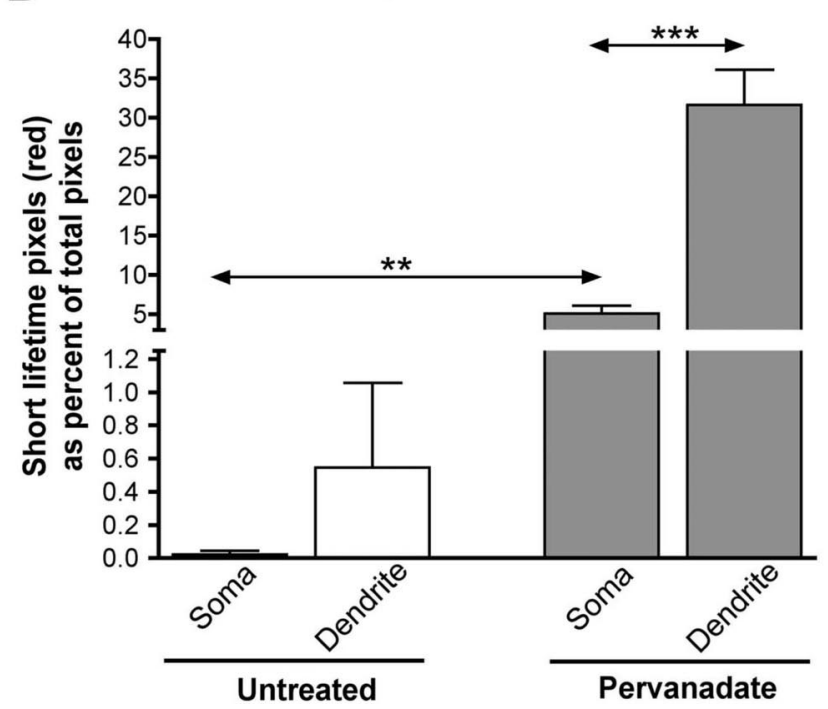

Figure 8. Inhibition of tyrosine phosphatases enhances the dendritic clustering of tyrosinephosphorylated NR2B subunit. $A$, Pervanadate-treated and untreated striatal neurons at DIV21 were double labeled for the NR2B subunit and phosphotyrosine proteins and subjected to fluorescence lifetime imaging microscopy analysis as described in Materials and Methods. $\boldsymbol{a}, \boldsymbol{b}$ Negative control experiment in which neurons were immunostained with only the donor fluorophore (Alexa Fluor 488). c, d, Untreated neurons double labeled for donor (Alexa Fluor 488, NR2B) and acceptor (Cy3, phosphotyrosine proteins) fluorophores. $\boldsymbol{e}, \boldsymbol{f}$, Pervanadate-treated neurons double labeled for donor (Alexa Fluor 488, NR2B) and acceptor (Cy3, phosphotyrosine proteins) fluorophores. Intensity images of the Alexa Fluor 488 staining for negative control $(\boldsymbol{a})$, untreated (c), and pervanadate-treated (e) cells. Color-coded FLIM images of the Alexa Fluor 488 lifetimes of negative control $(\boldsymbol{b})$, untreated $(\boldsymbol{d})$, and pervanadate-treated $(\boldsymbol{f})$ neurons. Pseudocolored FLIM images are presented for clarity using discrete colors to designate different fluorescence lifetimes: red (short lifetimes), between 200 and 1000 ps; green (moderate lifetimes), 1001-2000 ps; blue (long lifetimes), 2001-2500 ps. Both red and green denote FRETing populations (shorter Alexa Fluor 488 lifetime reflects closer NR2B and phosphotyrosine protein proximity), representing functionally active phospho-NR2B proteins. A population with a majority of non-FRETing NR2B proteins (longer Alexa Fluor 488 lifetime, NR2B and phosphotyrosine protein are far apart) is shown in blue. $B$, Quantitation of fluorescence lifetimes of FRETing and non-FRETing populations of NR2B proteins. Histograms (mean \pm SEM) show shorter phosphotyrosine protein in the postsynaptic density (Moon et al., 1994). The major site for tyrosine phosphorylation of NR2B is Tyr1472, a substrate for the Src family kinase Fyn (Moon et al., 1994; Suzuki and Okumura-Noji, 1995; Nakazawa et al., 2001). We showed previously that Fyn knock-out mice lack dopamine $\mathrm{D}_{1}$-dependent redistribution of striatal NMDA receptors (Dunah et al., 2004). A scaffolding protein, receptor for activated C kinase-1, has been shown to link Fyn and NR2B proteins, maintaining physical approximation and participating in regulation of NR2B phosphorylation (Yaka et al., 2002). Our results demonstrate that activation of the $\mathrm{D}_{1}$ receptor enhances phosphorylation of NR2B at Tyr1472. In addition, Tyr1472 is also a site for interaction of the clathrin adapter activator protein-2; thus, phosphorylation of Tyr1472 may promote synaptic stability of NR2B by preventing clathrin-dependent internalization (Lavezzari et al., 2003; Prybylowski et al., 2005).

Our FLIM data further corroborate the importance of NR2B tyrosine phosphorylation and also reveal the dynamic aspects of the process. This method has important advantages and disadvantages compared with conventional immunocytochemical approaches to studying phosphoproteins. Antibodies recognizing phosphorylated subunits can be used for immunohistochemical localization (Lau and Huganir, 1995; Hall and Soderling, 1997; Dunah et al., 1998), but it is difficult to demonstrate their specificity in situ, especially under conditions of nonselective tyrosine phosphatase inhibition. In contrast, the FLIM method relies on detecting the physical approximation of two well characterized antibodies, one on the carboxy tail of NR2B and the other to phosphotyrosine proteins, producing a signal when the two fluorophores are $<100 \AA$ apart (Spoelgen et al., 2006). A limitation of the FLIM method, however, is that it may not distinguish between direct phosphorylation of NR2B and tyrosine phosphorylation of another protein that interacts with the carboxy tail of NR2B. Because NR2B is the dominant phosphoprotein found in the PSD (Moon et al., 1994), it is likely that the majority of the signal is attributable to direct NR2B phosphorylation.

Using the FLIM method, we found that, under basal conditions, NR2B protein is present in both the neuronal soma and dendrites, but tyrosine-phosphorylated NR2B was concentrated in clusters along dendritic shafts. Inhibition of tyrosine phosphatases with pervanadate produced a marked enhancement of the abundance of tyrosine-phosphorylated NR2B with a strong gradient in favor of dendritic, rather than somatic, localization. This implies that either phosphorylation of NR2B occurs primarily in the dendrites or phosphorylation in the cell body results in the rapid translocation of NR2B to dendrites.

\section{Physiological significance of striatal NMDA receptor trafficking}

Dopamine-dependent trafficking of striatal NMDA receptors is likely important both for physiological regulation of synaptic strength, such as occurs in motor learning, and in the pathological state in Parkinson's disease (Picconi et al., 2005; Pisani et al., 2005). Experimentally, a major mechanism for strengthening of corticostriatal connections is long-term potentiation, which requires both NMDA receptor activity and dopaminergic input (Calabresi et al., 1992; Partridge et al., 2000). In dopamine deple-

$\leftarrow$

fluorescence lifetimes (red) in pixels expressed as percentage of total fluorescence lifetimes (red, green, and blue) in the cell soma (white bars) and dendrites (gray bars) for control and pervanadate-treated neurons. ${ }^{* *} p<0.01 ;{ }^{* * *} p<0.01$. 
tion that models Parkinson's disease, NMDA receptors are altered and striatal long-term potentiation is absent (Centonze et al., 1999). Long-term potentiation can be restored by chronic dopaminergic treatment, but, in animal models and humans with Parkinson's disease, such treatment is associated with the development of dyskinesias (Chase, 2004). Dyskinesias can be prevented or attenuated by low doses of NMDA antagonists in rodent models (Hallett and Standaert, 2004). In animal models, dopamine depletion leads to loss of NR1 and NR2B subunits from striatal membranes, whereas dyskinetic animals have normalized or increased NMDA receptors in synaptic compartments (Dunah et al., 2000; Hallett et al., 2005). In these animals, longterm potentiation is persistent and can no longer be depotentiated by a subsequent low-frequency stimulus (Picconi et al., 2003). Together, these observations reveal dysregulation of NMDA receptors in the pathogenesis of parkinsonism and dyskinesia (Chase and Oh, 2000; Hallett and Standaert, 2004; Hallett et al., 2005).

The findings from this investigation demonstrate that a major mechanism for the dopaminergic modulation of striatal NMDA receptors is enhanced dendritic localization, clustering, and surface expression of NMDA subunits, regulated by the action of $D_{1}$ receptors and tyrosine phosphatases and kinases. Because alterations in NMDA receptor function contribute to the clinical features of Parkinson's disease and may underlie the development of dyskinesias, therapies targeted at interrupting or regulating striatal NMDA receptor trafficking may be useful in the treatment of Parkinson's disease.

\section{References}

Bacskai BJ, Hickey GA, Skoch J, Kajdasz ST, Wang Y, Huang GF, Mathis CA, Klunk WE, Hyman BT (2003) Four-dimensional multiphoton imaging of brain entry, amyloid binding, and clearance of an amyloid-beta ligand in transgenic mice. Proc Natl Acad Sci USA 100:12462-12467.

Berezovska O, Ramdya P, Skoch J, Wolfe MS, Bacskai BJ, Hyman BT (2003) Amyloid precursor protein associates with a nicastrin-dependent docking site on the presenilin $1-\gamma$-secretase complex in cells demonstrated by fluorescence lifetime imaging. J Neurosci 23:4560-4566.

Boulanger LM, Lombroso PJ, Raghunathan A, During MJ, Wahle P, Naegele JR (1995) Cellular and molecular characterization of a brain-enriched protein tyrosine phosphatase. J Neurosci 15:1532-1544.

Calabresi P, Maj R, Pisani A, Mercuri NB, Bernardi G (1992) Long-term synaptic depression in the striatum: physiological and pharmacological characterization. J Neurosci 12:4224-4233.

Carroll RC, Zukin RS (2002) NMDA-receptor trafficking and targeting: implications for synaptic transmission and plasticity. Trends Neurosci 25:571-577.

Centonze D, Gubellini P, Picconi B, Calabresi P, Giacomini P, Bernardi G (1999) Unilateral dopamine denervation blocks corticostriatal LTP. J Neurophysiol 82:3575-3579.

Centonze D, Grande C, Saulle E, Martin AB, Gubellini P, Pavon N, Pisani A, Bernardi G, Moratalla R, Calabresi P (2003) Distinct roles of $\mathrm{D}_{1}$ and $\mathrm{D}_{5}$ dopamine receptors in motor activity and striatal synaptic plasticity. J Neurosci 23:8506-8512.

Cepeda C, Buchwald NA, Levine MS (1993) Neuromodulatory actions of dopamine in the neostriatum are dependent upon the excitatory amino acid receptor subtypes activated. Proc Natl Acad Sci USA 90:9576-9580.

Cepeda C, Colwell CS, Itri JN, Chandler SH, Levine MS (1998) Dopaminergic modulation of NMDA-induced whole cell currents in neostriatal neurons in slices: contribution of calcium conductances. J Neurophysiol 79:82-94.

Chase TN (2004) Striatal plasticity and extrapyramidal motor dysfunction. Parkinsonism Relat Disord 10:305-313.

Chase TN, Oh JD (2000) Striatal dopamine- and glutamate-mediated dysregulation in experimental parkinsonism. Trends Neurosci 23:S86-S91.

Day M, Wang Z, Ding J, An X, Ingham CA, Shering AF, Wokosin D, Ilijic E, Sun Z, Sampson AR, Mugnaini E, Deutch AY, Sesack SR, Arbuthnott GW, Surmeier DJ (2006) Selective elimination of glutamatergic synapses on striatopallidal neurons in Parkinson disease models. Nat Neurosci 9:251-259.

Di Chiara G, Morelli M, Consolo S (1994) Modulatory functions of neurotransmitters in the striatum: ACh/dopamine/NMDA interactions. Trends Neurosci 17:228-233.

Dingeldine R, Borges K, Bowie D, Traynelis SF (1999) The glutamate receptor ion channels. Pharmacol Rev 51:7-61.

Dunah AW, Standaert DG (2001) Dopamine $\mathrm{D}_{1}$ receptor-dependent trafficking of striatal NMDA glutamate receptors to the postsynaptic membrane. J Neurosci 21:5546-5558.

Dunah AW, Yasuda RP, Wolfe BB (1998) Developmental regulation of tyrosine phosphorylation of the NR2D NMDA glutamate receptor subunit in rat central nervous system. J Neurochem 71:1926-1934.

Dunah AW, Wang YH, Yasuda RP, Kameyama K, Huganir RL, Wolfe BB, Standaert DG (2000) Alterations in subunit expression, composition and phosphorylation of striatal NMDA glutamate receptors in the rat 6-OHDA models of Parkinson's disease. Mol Pharmacol 57:342-352.

Dunah AW, Sirianni AC, Fienberg AA, Bastia E, Schwarzschild MA, Standaert DG (2004) Dopamine D1-dependent trafficking of striatal $N$-methyl-Daspartate glutamate receptors requires Fyn protein tyrosine kinase but not DARPP-32. Mol Pharmacol 65:121-129.

Dunah AW, Hueske E, Wyszynski M, Hoogenraad CC, Jaworski J, Pak DT, Simonetta A, Liu G, Sheng M (2005) LAR receptor protein tyrosine phosphatases in the development and maintenance of excitatory synapses. Nat Neurosci 8:458-467.

Falk T, Zhang S, Erbe EL, Sherman SJ (2006) Neurochemical and electrophysiological characteristics of rat striatal neurons in primary culture. J Comp Neurol 494:275-289.

Flores-Hernandez J, Cepeda C, Hernandez-Echeagaray E, Calvert CR, Jokel ES, Fienberg AA, Greengard P, Levine MS (2002) Dopamine enhancement of NMDA currents in dissociated medium-sized striatal neurons: role of D1 receptors and DARPP-32. J Neurophysiol 88:3010-3020.

Goslin K, Banker G (1991) Culturing nerve cells. Cambridge, MA: MIT.

Grosshans DR, Clayton DA, Coultrap SJ, Browning MD (2002) LTP leads to rapid surface expression of NMDA but not AMPA receptors in adult rat CA1. Nat Neurosci 5:27-33.

Hall RA, Soderling TR (1997) Differential surface expression and phosphorylation of the $N$-methyl-D-aspartate receptor subunits NR1 and NR2 in cultured hippocampal neurons. J Biol Chem 272:4135-4140.

Hallett PJ, Standaert DG (2004) Rationale for and use of NMDA receptor antagonists in Parkinson's disease. Pharmacol Ther 102:155-174.

Hallett PJ, Dunah AW, Ravenscroft P, Zhou S, Bezard E, Crossman AR, Brotchie JM, Standaert DG (2005) Alterations of striatal NMDA receptor subunits associated with the development of dyskinesia in the MPTPlesioned primate model of Parkinson's disease. Neuropharmacology 48:503-516.

Hersch SM, Ciliax BJ, Gutekunst C-A, Rees HD, Heilman CJ, Yung KKL, Bolam JP, Ince E, Yi H, Levey AI (1995) Electron microscopic analysis of $\mathrm{D}_{1}$ and $\mathrm{D}_{2}$ dopamine receptor proteins in the dorsal striatum and their synaptic relationships with motor corticostriatal afferents. J Neurosci 15:5222-5237.

Kawaguchi Y, Wilson CJ, Augood Sj, Emson PC (1995) Striatal interneurons: chemical, physiological, and morphological characterization. Trends Neurosci 18:527-535.

Kennedy MB (1997) The postsynaptic density at glutamatergic synapses. Trends Neurosci 20:264-268.

Kerr JN, Wickens JR (2001) Dopamine D-1/D-5 receptor activation is required for long-term potentiation in the rat neostriatum in vitro. J Neurophysiol 85:117-124.

Kosinski CM, Standaert DG, Counihan TJ, Scherzer CR, Kerner JA, Daggett LP, Velicelebi G, Penney JB, Young AB (1998) Expression of N-methylD-aspartate receptor subunit mRNA in the human neostriatum and globus pallidus. J Comp Neurol 390:63-74.

Lau LF, Huganir RL (1995) Differential tyrosine phosphorylation of N-methyl-D-aspartate receptor subunits. J Biol Chem 270:20036-20041.

Lavezzari G, McCallum J, Lee R, Roche KW (2003) Differential binding of the AP-2 adaptor complex and PSD-95 to the C-terminus of the NMDA receptor subunit NR2B regulates surface expression. Neuropharmacology 45:729-737.

Levine MS, Altemus KL, Cepeda C, Cromwell HC, Crawford C, Ariano MJ, Drago J, Sibley DR, Westphal H (1996) Modulatory actions of dopa- 
mine on NMDA receptor-mediated responses are reduced in $\mathrm{D}_{1 \mathrm{~A}^{-}}$ deficient mutant mice. J Neurosci 16:5870-5882.

Lin JW, Ju W, Foster K, Lee SH, Ahmadian G, Wyszynski M, Wang YT, Sheng M (2000) Distinct molecular mechanisms and divergent endocytotic pathways of AMPA receptor internalization. Nat Neurosci 3:1282-1290.

Liu L, Wong TP, Pozza MF, Lingenhoehl K, Wang Y, Sheng M, Auberson YP, Wang YT (2004) Role of NMDA receptor subtypes in governing the direction of hippocampal synaptic plasticity. Science 304:1021-1024.

McIlhinney RA, Le Bourdelles B, Molnar E, Tricaud N, Streit P, Whiting PJ (1998) Assembly intracellular targeting and cell surface expression of the human $N$-methyl-D-aspartate receptor subunits NR1a and NR2A in transfected cells. Neuropharmacology 37:1355-1367.

Menegoz M, Lau L-F, Hervé D, Huganir RL, Girault J-A (1996) Tyrosine phosphorylation of NMDA receptor in rat striatum: effects of 6-OHdopamine lesions. NeuroReport 7:125-128.

Monyer H, Burnashev N, Laurie DJ, Sakmann B, Seeburg PH (1994) Developmental and regional expression in the rat brain and functional properties of four NMDA receptors. Neuron 12:529-540.

Moon IS, Apperson ML, Kennedy MB (1994) The major tyrosinephosphorylated protein in the postsynaptic density fraction is $\mathrm{N}$-methylD-aspartate receptor subunit 2B. Proc Natl Acad Sci USA 91:3954-3958.

Nakazawa T, Komai S, Tezuka T, Hisatsune C, Umemori H, Semba K, Mishina M, Manabe T, Yamamoto T (2001) Characterization of Fynmediated tyrosine phosphorylation sites on GluR epsilon 2(NR2B) subunit of the $N$-methyl-D-aspartate receptor. J Biol Chem 276:693-699.

Oh JD, Russell D, Vaughan CL, Chase TN (1998) Enhanced tyrosine phosphorylation of striatal NMDA receptor subunits: effect of dopaminergic denervation and L-DOPA administration. Brain Res 813:150-159.

Partridge JG, Tang KC, Lovinger DM (2000) Regional and postnatal heterogeneity of activity-dependent long-term changes in synaptic efficacy in the dorsal striatum. J Neurophysiol 84:1422-1429.

Paul S, Snyder GL, Yokakura H, Picciotto MR, Nairn AC, Lombroso PJ (2000) The dopamine/ $D_{1}$ receptor mediates the phosphorylation and inactivation of the protein tyrosine phosphatase STEP via a PKAdependent pathway. J Neurosci 20:5630-5638.

Pelkey KA, Askalan R, Paul S, Kalia LV, Nguyen TH, Pitcher GM, Salter MW, Lombroso PJ (2002) Tyrosine phosphatase STEP is a tonic brake on induction of long-term potentiation. Neuron 34:127-138.

Petralia RS, Wang Y-X, Wenthold RJ (1994) The NMDA receptor subunits NR2A and NR2B show histological and ultrastructural localization patterns similar to those of NR1. J Neurosci 14:6102-6120.

Picconi B, Centonze D, Hakansson K, Bernardi G, Greengard P, Fisone G, Cenci MA, Calabresi P (2003) Loss of bidirectional striatal synaptic plasticity in L-DOPA-induced dyskinesia. Nat Neurosci 6:501-506.

Picconi B, Pisani A, Barone I, Bonsi P, Centonze D, Bernardi G, Calabresi P (2005) Pathological synaptic plasticity in the striatum: implications for Parkinson's disease. Neurotoxicology 26:779-783.

Pisani A, Centonze D, Bernardi G, Calabresi P (2005) Striatal synaptic plasticity: implications for motor learning and Parkinson's disease. Mov Disord 20:395-402.

Prybylowski K, Chang K, Sans N, Kan L, Vicini S, Wenthold RJ (2005) The synaptic localization of NR2B-containing NMDA receptors is controlled by interactions with PDZ proteins and AP-2. Neuron 47:845-857.

Rosenblum K, Dudai Y, Richter LG (1996) Long-term potentiation increases tyrosine phosphorylation of the $\mathrm{N}$-methyl-D-aspartate receptor subunit $2 \mathrm{~B}$ in rat dentate gyrus in vivo. Proc Natl Acad Sci USA 93:10457-10460.

Rostas JA, Brent VA, Voss K, Errington ML, Bliss TV, Gurd JW (1996) En- hanced tyrosine phosphorylation of the 2B subunit of the $N$-methyl-Daspartate receptor in long-term potentiation. Proc Natl Acad Sci USA 93:10452-10456.

Sans N, Petralia RS, Wang YX, Blahos II J, Hell JW, Wenthold RJ (2000) A developmental change in NMDA receptor-associated proteins at hippocampal synapses. J Neurosci 20:1260-1271.

Sans N, Prybylowski K, Petralia RS, Chang K, Wang YX, Racca C, Vicini S, Wenthold RJ (2003) NMDA receptor trafficking through an interaction between PDZ proteins and the exocyst complex. Nat Cell Biol 5:520-530.

Segal M, Greenberger V, Korkotian E (2003) Formation of dendritic spines in cultured striatal neurons depends on excitatory afferent activity. Eur J Neurosci 17:2573-2585.

Setou M, Nakagawa T, Seog DH, Hirokawa N (2000) Kinesin superfamily motor protein KIF17 and mLin-10 in NMDA receptor- containing vesicle transport. Science 288:1796-1802.

Sheng M, Cummings J, Roldan LA, Jan YN, Jan LY (1994) Changing subunit composition of heteromeric NMDA receptors during development. Nature 368:144-147.

Smith Y, Kieval JZ (2000) Anatomy of the dopamine system in the basal ganglia. Trends Neurosci 23:S28-S33.

Smith Y, Bennett BD, Bolam JP, Parent A, Sadikot AF (1994) Synaptic relationships between dopaminergic afferents and cortical or thalamic input in the sensorimotor territory of the striatum in monkey. J Comp Neurol 344:1-19.

Smith Y, Bevan MD, Shink E, Bolam JP (1998) Microcircuitry of the direct and indirect pathways of the basal ganglia. Neuroscience 86:353-387.

Snyder EM, Nong Y, Almeida CG, Paul S, Moran T, Choi EY, Nairn AC, Salter MW, Lombroso PJ, Gouras GK, Greengard P (2005) Regulation of NMDA receptor trafficking by amyloid-beta. Nat Neurosci 8:1051-1058

Spoelgen R, von Arnim CA, Thomas AV, Peltan ID, Koker M, Deng A, Irizarry MC, Andersen OM, Willnow TE, Hyman BT (2006) Interaction of the cytosolic domains of sorLA/LR11 with the amyloid precursor protein (APP) and $\beta$-secretase $\beta$-site APP-cleaving enzyme. J Neurosci 26:418-428.

Standaert DG, Testa CM, Penney JB, Young AB (1994) Organization of $\mathrm{N}$-methyl-D-aspartate glutamate receptor gene expression in the basal ganglia of the rat. J Comp Neurol 343:1-16.

Suzuki T, Okumura-Noji K (1995) NMDA receptor subunits epsilon 1 (NR2A) and epsilon 2 (NR2B) are substrates for Fyn in the postsynaptic density fraction isolated from the rat brain. Biochem Biophys Res Commun 216:582-588.

Wang Y-H, Bosy TZ, Yasuda RP, Grayson DR, Vicini S, Pizzorusso R, Wolfe BB (1995) Characterization of NMDA receptor subunit-specific antibodies: distribution of NR2A and NR2B receptor subunits in the rat brain and ontogenic profile in cerebellum. J Neurochem 65:176-183.

Wenthold RJ, Prybylowski K, Standley S, Sans N, Petralia RS (2003) Trafficking of NMDA receptors. Annu Rev Pharmacol Toxicol 43:335-358.

Wittmann M, Marino MJ, Henze DA, Seabrook GR, Conn PJ (2005) Clozapine potentiation of $\mathrm{N}$-methyl-D-aspartate receptor currents in the nucleus accumbens: role of NR2B and protein kinase A/Src kinases. J Pharmacol Exp Ther 313:594-603.

Wyszynski M, Kim E, Dunah AW, Passafaro M, Valtschanoff JG, Serra-Pages C, Streuli M, Weinberg RJ, Sheng M (2002) Interaction between GRIP and liprin-alpha/SYD2 is required for AMPA receptor targeting. Neuron 34:39-52.

Yaka R, Thornton C, Vagts AJ, Phamluong K, Bonci A, Ron D (2002) NMDA receptor function is regulated by the inhibitory scaffolding protein, RACK1. Proc Natl Acad Sci USA 99:5710-5715. 